Komunike, Volume XII, No. 2 Desember 2020

\title{
STRATEGI KOMUNIKASI KPID JAWA TIMUR DALAM MENCEGAH PENYEBARAN VIRUS CORONA
}

\author{
Amalia Rosyadi Putri \\ Institut Agama Islam Tribakti Kediri \\ amaliarosyadi16@gmail.com \\ Ellyda Retpitasari \\ Institut Agama Islam Tribakti Kediri \\ ellydaretpitasari@gmail.com
}

\begin{abstract}
This research is motivated by a phenomenon that occurred in early March 2020, namely the increase in positive cases of Corona in East Java. Various broadcasting media, both television and radio, are competing to broadcast the outbreak. Likewise the East Java KPID as an independent state institution has participated in overcoming panic and efforts to prevent the Corona outbreak. This study aims to describe the communication strategy of the East Java KPID in preventing the spread of the Corona outbreak using the analysis knife The Pervasive Presence. The method used is qualitative with a phenomenological approach. The research findings resulted in a description of the East Java KPID Communication Strategy, East Java Komisi Penyiaran Indonesia Daerah (KPID) Social Media Optimization and the East Java KPID Communication Strategy in Preventing the Spread of Outbreaks. The conclusion from the results of the study on the communication strategy of the East Java KPID in tackling the spread of the Corona outbreak consists of three strategies, namely by live Talkshows on television and radio, distributing circulars to radio and television broadcasting institutions throughout East Java via email and WhatsApp, and publication of information through social media, namely the East Java KPID Instagram. These three communication strategies are part of the task of the East Java KPID in supervising broadcasting institutions and media literacy to the public.
\end{abstract}

Keywords: Communication Strategy, East Java KPID, Corona Virus 
Komunike, Volume XII, No. 2 Desember 2020

\begin{abstract}
Abstrak
Penelitian ini dilatarbelakangi atas fenomena yang terjadi pada awal Maret 2020 yaitu meningkatnya kasus positif Corona di Jawa Timur. Berbagai media penyiaran baik televisi maupun radio berlomba-lomba menyiarkan adanya wabah ini. Begitu pula Komisi Penyiaran Indonesia Daerah (KPID) Jawa Timur sebagai lembaga independen negara ikut serta menanggulangi kepanikan dan upaya pencegahan wabah Corona. Penelitian ini bertujuan untuk mendeskripsikan strategi komunikasi KPID Jawa Timur dalam pencegahan penyebaran wabah Corona dengan menggunakan pisau analisis The Pervasive Presence. Metode yang dipakai adalah kualitatif dengan pendekatan fenomenologi. Adapun temuan penelitian menghasilakan deskripsi atas Strategi Komunikasi KPID Jawa Timur, Optimalisasi Media Sosial KPID Jawa Timur dan Strategi Komunikasi KPID Jawa Timur dalam Pencegahan Penyebaran Wabah. Kesimpulan dari hasil kajian atas strategi komunikasi KPID Jawa Timur dalam menanggulangi penyebaran wabah Corona terdiri dari tiga strategi yaitu dengan Talkshow langsung di televisi dan radio, penyebaran surat edaran kepada lembaga penyiaran radio dan televisi di seluruh Jawa Timur melalui email dan WhatsApp, dan publikasi informasi melalui media sosial yaitu instagram KPID Jawa Timur. Tiga strategi komunikasi ini menjadi bagian tugas KPID Jawa Timur dalam melakukan pengawasan lembaga penyiaran dan literasi media kepada masyarakat.
\end{abstract}

Kata Kunci: Strategi Komunikasi, KPID Jawa Timur, Virus Corona 
Komunike, Volume XII, No. 2 Desember 2020

\section{A. PENDAHULUAN}

Jawa Timur menjadi salah satu provinsi yang memiliki Jumlah penduduk yang terpadat kedua setelah Jakarta. Begitu pula atas penyebaran virus corona, hingga detik ini di Jawa Timur telah terjadi 65.012 kasus positif Corona dengan jumlah kasus meninggal dunia sebanyak 4.584 . Virus yang menginfeksi masyarakat Jawa Timur terhitung pada awal maret yang ditandai dengan gejala ringan hingga berat diantaranya Severe Acute Respiratory Syndrome (SARS-CoV) dan Middle East Respiratory Syndrome (MERSCoV). ${ }^{1}$

Meningkatnya angka kasus positif Corona menjadi pusat perhatian pemerintah daerah pada penanganan pandemi yang kian meresahkan masyarakat. Berbagai kebijakan dikeluarkan dan anggaran besarpun dialokasikan untuk megatasinya. Beberapa kebijakan yang dikeluarkan pemerintah Jawa Timur di antaranya Sosial Distancing,

\footnotetext{
${ }^{1}$ A.Ghofur \& B.Subahri. Konstruksi Sosial Keagamaan Masyarakat Pada Masa Pandemi Covid-19. DAKWATUNA: Jurnal Dakwah dan Komunikasi Islam. Volume 6, Nomor 2, Agustus 2020.
}

karantina kesehatan, yang kemudian dituangkan dalam PP Nomor 21 Tahun 2020 tentang Pembatasan Sosial Berskala Besar (PSBB) di beberapa kota besar seperti Surabaya, Malang dan di ikuti kota-kota lainnya di Jawa Timur.

Selanjutnya, Mendagri Tito Karnavian mengeluarkan Surat Edaran Nomor 440/2622/SJ tentang Pembentukan Gugus Tugas Percepatan Penanganan wabah virus corona di daerah. Aturan ini dikeluarkan pada Minggu 29 Maret 2020. Direktur Manajemen Penanggulangan Bencana dan Kebakaran Kementerian dalam Negeri Syafrizal mengatakan bahwa keberadaan Surat Edaran itu bertujuan agar kepala daerah menjadi ketua gugus tugas percepatan penanganan wabah virus corona yang berada di daerah tidak terkecuali di Jawa Timur. $^{2}$

$$
\text { Berbagai upaya dilakukan }
$$
pemerintah daerah Jawa TImur guna optimalisasi pencegahan wabah virus

2 Dian Erika Nugraheny. Mendagri Keluarkan Surat Edaran soal Pembentukan Gugus Tugas Penanganan Covid-19 di Daerah. Dikutip dari Kompas.com 
Corona yang semakin tak terkendali dan mulai meluas kepada pelosokpelosok desa sehingga perlu melakukan penanganan khusus juga informasi yang optimal sehingga setiap lapisan masyarakat mendapatkan dan informasi $U p$ to date juga terhindar dari berita hoax yang banyak dimanfaatkan oleh oknum-oknum yang tidak bertanggung jawab juga mencari celah dan memanfaatkan keadaan yang genting di tengah wabah pandemi.

Mengantisipasi akan penyebaran virus corona yang semakin meluas juga beredarnya berita-berita hoax seputar wabah virus corona, Komisi Penyiaran Indonesia Daerah (KPID) Jawa TImur juga dengan menindaklanjuti Surat Edaran Komisi Penyiaran Indonesia Pusat Nomor 156/PKP/KPI/31.2/03/2002 tentang peran lembaga Penyiaran ${ }^{3}$ dalam Penanggulangan Persebaran Wabah Corona seperti mendukung instruksi

3 Lembaga penyiaran merupakan penyelenggaran penyiaran, baik lembaga penyiaran publik (LPP), lembaga penyiaran swasta (LPS), lembaga penyiaran komunitas (LPK) maupun lembaga penyiaran berlangganan (LPB) yang dalam pemerintah dengan

menginformasikan melalui iklan layanan masyarakat tentang social distancing, dan pencegahan serta penanggulangan wabah Corona.

Komisi Penyiaran Indonesia (KPI) merupakan lembaga independen yang dibentuk berdasarkan Undang-Undang (UU) nomor 32 Tahun 2002 tentang penyiiaran, tepatnya mengatur segala hal dalam seputar penyiaran di Indonesia. Adapun dalam ranah provinsi, maka KPI Pusat berkordinasi dengan Lembaga Independen daerah yaitu Komisi Penyiaran Indonesia Daerah (KPID). KPID Jawa Timur juga selain melakukan komunikasi dan pengawasan dengan media lokal yang terdiri dari radio dan televisi juga berhubungan dengan masyarakat. Seperti diketahui bahwa setiap harinya masyarakat tidak terlepas dengan konsumsi media penyiaran televisi dan radio. Dengan adanya wabah Corona ini, menjadikan KPID

melaksanakan tugas, fungsi, dan tanggung jawabnya berpedoman pada peraturan perundang-undangan yang berlaku, UndangUndang No.32 Tahun 2002 tentang penyiaran Bab 1, pasal 1, ayat 7 . 
Komunike, Volume XII, No. 2 Desember 2020

Jawa Timur melakukan beberapa timdakan untuk mengedukasi masyarakat dan meliterasi media masyarakat tentang adanya wabah Corona. KPID Jawa Timur melakukan komunikasi dengan lembaga penyiaran televisi dan radio, kedua media massa ini memiliki peranan penting dalam menyebarkan informasi dan membentuk opini public agar tidak cemas tetapi tetap waspada dalam menghadapi wabah Corona. Upaya ini guna mencegah dan menanggulangi berita hoax yang menyebar dan menakut-nakuti masyarakat tentang adanya wabah Corona.

\section{B. TINJAUAN PUSTAKA}

Berdasarkan uraian tentang wabah pandemi Corona, maka penelitian ini bertujuan menjelaskan bagaimana strategi komunikasi KPID Jawa Timur dalam Pencegahan Penyebaran Wabah Virus Corona dengan melalui analisis teori the pervasive presence theory atau

\footnotetext{
4 Masduki, Regulasi Penyiaran: dari Otoriter ke Liberal, (Yogyakarta: LKIS Yogyakarta, 2007), 5

${ }^{5}$ M. Aminullah \& Ali, M. Konsep Pengembangan Diri Dalam Menghadapi
}

pengelolaan media penyiaran. Teori ini berisi asumsi tentang media penyiaran memiliki dominasi yang kuat dalam mempengaruhi masyarakat melalui pesan yang ofensif dan masuk pada wilayah pribadi, maka dari itu media perlu diatur agar masyarakat mendapat rujukan media yang dapat mewadahi aspirasi dan melindungi masyarakat dari maraknya informasi yang tidak benar $(\text { hoax })^{4}$.

Ada sejumlah riset yang dijadikan rujukan dari kajian ini. Salah satunya, tentang pentingnya tiap orang, kelompok masyarakat, termasuk Lembaga negara untuk melakukan revolusi komunikasi di era media baru ${ }^{5}$. Hal itu dilakukan demi menjawab tantangan zaman. Riset yang juga dijadikan referensi adalah tentang pentingnya menggunakan teknologi informasi dan komunikasi dalam melakukan pencegahan atau penyebaran Corona dan melakukan komunikasi multikultural di masyarakat ${ }^{6}$. Beberapa kajian pustaka

Perkembangan Teknologi Komunikasi Era 4.0. KOMUNIKE, 12(1), 1-23, 2020

6 A. Kurniawan, Yumna, N., \& Tantri, E. Resistensi Ruang Publik Di Tengah Covid-19 Perspektif Islam Dan Komunikasi 
yang relevan dengan penelitian ini ialah sebagai berikut:

Pertama: Penelitian dengan judul "Konstruksi Sosial Keagamaan Masyarakat Pada Masa Pandemi Covid-19" yang ditulis Abdul Ghofur dan Bambang Subahri dan diterbitkan dalam jurnal Dakwatuna: Jurnal Dakwah dan Komunikasi Islam Volume 6, Nomor 2, Agustus 2020. Penelitian ini menggunakan konsep teoritik menurut Peter L. Berger dengan kerangka konstruksi sosial. Pada penelitian ini memiliki persamaan obyek tentang yaitu wabah virus korona, namun konsep teoritik yang ditawarkan merupakan ranah pada kajian sosial keagamaan, dimana peran media yang menjadi ujung tombak dalam penerimaan informasi belum terungkap dalam penelitian ini. $^{7}$

Kedua: Rizqon Halal Syah Aji dalam jurnal SALAM; Jurnal Sosial \& Budaya Syar-i FSH UIN Syarif Hidayatullah Jakarta dengan judul

Multikultural. KOMUNIKE, 12(1), 24-40, 2020

${ }^{7}$ A.Ghofur \& B.Subahri. Konstruksi Sosial ..., 2020.

${ }^{8}$ R. H. S, Aji. Dampak Covid-19 pada Pendidikan di Indonesia: Sekolah, Keterampilan, dan Proses Pembelajaran.
"Dampak Covid-19 pada Pendidikan di Indonesia: Sekolah, Keterampilan, dan Proses Pembelajaran". Senada dengan kajian pustaka sebelumnya pada penelitian ini memiliki kesamaan obyek namun memiliki perbedaan perspektif teori yaitu menggunakan sudut pandang pendidikan dalam menganalisa dampak wabah virus Corona. ${ }^{8}$

Ketiga: Penelitian yang dilakukan Abdurrahman Firdaus Thaha yakni membahas persoalan tentang usaha kecil dan menengah (UMKM) berada di garis depan guncangan ekonomi yang disebabkan oleh pandemi COVID-19. Ini juga selaras dengan berapa penelitian di atas namun menggunakan analisa teori berdasarkan konsepsi ekonomi sedangkan pada penelitian, peneliti menggunakan analisis media dan ilmu komunikasi. ${ }^{9}$

Keempat: Penelitian yang dilakukan Arsa Widitiarsa Utoyo memiliki kesamaan dari pisau analisa

SALAM; Jurnal Sosial \& Budaya Syar-i FSH UIN Syarif Hidayatullah Jakarta Vol. 7 No. 5 (2020), pp. 395-402, DOI: 10.15408/sjsbs.v7i5.15314

9 A. F, Thaha. Dampak Covid-19 Terhadap Umkm Di Indonesia. Jurnal Brand, Volume 2 No. 1, Juni 2020. 
Komunike, Volume XII, No. 2 Desember 2020

yaitu konsepsi komunikasi namun dalam hal ini juga memiliki perbedaan yang mencolok yaitu media dalam penelitian yang dilakukan oleh Arsya merupakan Media visual sedangkan yang dilakukan dalam penelitian ini merupakan adalah strategi komunikasi dengan menggunakan media digital ${ }^{10}$

Dari keempat kajian pustaka yang telah peneliti rangkum dalam penelitian ini, penelitian ini memiliki beberapa perbedaan yaitu menganalisa strategi komunikasi dalam pencegahan virus Corona, sehingga tidak sekedar upaya menganalisa dampak yang ditimbulkan dari virus Corona, melainkan juga telah melangkah kepada tahap bagaimana pencegahan yang optimal menggunakan strategi komunikasi.

\section{METODE PENELITIAN}

Penelitian yang digunakan dalam riset ini menggunakan

10 A. W, Utoyo. Analisis Komunikasi Visual Pada Poster Sebagai Media Komunikasi Mendorong Jarak Sosial Di Jakarta Saat Epidemi Covid 19. Jurnal Lugas Vol. 4, No.1, Juni 2020, pp. 35 - 42 pendekatan kualitatif dengan jenis fenomenologi. ${ }^{11}$ Penelitian kualitatif bergantung dari pengamatan pada manusia, baik dalam kawasannya maupun peristilahannya. ${ }^{12}$ Selanjutnya jenis penelitian fenomenologi bisa difahami sebagai proses mencari pemahaman mendalam serta berusaha mengungkap arti peristiwa dan kaitannya terhadap orang-orang yang berada dalam situasi tertentu dengan menggunakan metode interpretasi yang sama dengan orang yang diamati.

Fenomenologi berasal dari bahasa Yunani, 'Phainomenon' yaitu yang menampak. Pendekatan fenomenologis untuk mempelajari kepribadian dipusatkan pada pengalaman individual pandangannya pribadi terhadap dunia ${ }^{13}$. Alfred Schutz adalah ahli toeri fenomenologi yang paling menonjol sekaligus yang membuat fenomenologi menjadi ciri khas bagi ilmu sosial hingga saat ini. inti pemikiran Schutz adalah

11 Lexy J. Moleong, Metodologi Penelitian Kualitatif (Bandung: PT. Rosda Karya, 2008), hal 3

${ }^{12}$ Lexy, hal 4

${ }^{13}$ Rita L Atkinson, dkk, Pengantar Psikologi. (Tangerang: Interaksara, 2010). 5 
Komunike, Volume XII, No. 2 Desember 2020

bagaimana memahami tindakan sosial (yang berorientasi pada perilakuk orang atau orang lain pada masa lalu, sekarang dan akan datang) melalui penafsiran. ${ }^{14}$

Data dalam penelitian ini diperoleh dengan cara observasi dan wawancara dengan beberapa informan (nara sumber) juga dilakukan studi pustaka. Observasi dilakukan melalui media televisi dan radio. Selanjutnya peneliti melakukan media monitoring terkait iklan layanan masyarakat tentang wabah corona. Sedangkan untuk wawancara dilakukan dengan informan yang terkait. Kemudian untuk melengkapi data, peneliti melakukan studi pustaka yang dilakukan dengan menelusuri topik-topik yang berkaitan dengan fenomena strategi komunikasi, dan pemberitaan wabah virus corona.

\section{HASIL DAN PEMBAHASAN}

Dalam menjalankan tugas dan wewenangnnya KPID Jawa Timur menyusun beberapa strategi

\footnotetext{
${ }^{14}$ Moleong, 14-17.

15 Rio Febriannur Rachman \& Ilmaniya, S. SOMUNIKASI ANTARBUDAYA DI PONDOK PESANTREN (Studi Kasus di Pondok Pesantren Putri Miftahul Ulum Banyuputih
}

komunikasi sebagai sistem pencapaian visi dan misi KPID Jawa Timur. Maksud strategi komunikasi adalah perencanaan yang dibuat komunikator agar pesan yang disampaikan dapat diterima, dimengerti dan dijalankan oleh komunikan. Tujuan dari strategi komunikasi yaitu komunikan mengerti apa yang komunikator sampaikan, Andai kata ia sudah dapat mengerti juga telah menerima, maka penerimanya diberikan pembinaan agar komunikan mengerti apa yang dinginkan oleh komunikator dan pada akhirnya kegiatan itu dimotivasikan agar komunikan lebih.

Keberhasilan suatu komunikasi salah satunya ditentukan dari aspek strategi. Segala perbedaan, baik budaya, latar belakang, dan lain sebagainya, bisa disiasati dengan strategi yang baik $^{15}$. Dikutip dari Poerwadarminta dalam Kamus Umum Bahasa Indonesia menyatakan bahwa strategi merupakan cara atau taktik. Menurut Bennet ${ }^{16}$ Strategi

\footnotetext{
Lumajang). Al-Insyiroh: Jurnal Studi Keislaman, 6(2), 61-84, 2020

16 Onong Uchjana Effendy. Ilmu Komunikasi Teori dan Praktek. Bandung: PT Remaja Rosdakarya, 2006. 36
} 
Komunike, Volume XII, No. 2 Desember 2020

merupakan sebuah cara dalam mencapi visi dan misi dalam sebuah organisasi melalui penentuan arah yang dipilih. Sedangkan, Anwar Arifin menyatakan bahwa strategi merupakan keseluruhan dari keputusan kondisiaonal dalam mencapai tujuan melalui sebuah tindakan-tindakan yang dijalankan ${ }^{17}$. Setidaknya ada lima poin penting yang dilaukan KPID Jawa Timur berkaitan dengan strategi tersebut, yakni;

a. Strategi as a plan. Strategi dalam pengertian ini berupa rencana yang menjadi acuan dan landasan dalam suatu organisasi guna mencapai sasaran dan tujuan yang ditetapkan oleh KPID Jawa Timur.

b. Strategi as a pattern. Strategi merupakan sebuah pola suatu tindakan organisasi yang continue dan konsisten berjalan dalam waktu yang jangka lama.

c. Strategi as position. strategi yang berbentuk cara organisasi dalam menempatkan atau

\begin{tabular}{lccr}
\hline 17 & Anwar & Arifin. & Strategi \\
Komunikasi & Sebuah & Pengantar & Ringkas. \\
Bandung: CV Armico, 2007. 59 &
\end{tabular}

mengalokasikan sesuatu pada tempatnya sesuai dengan posisi, situasi, dan kondisi.

d. Strategi as a perspective. strategi ialah cara pandang sebuah organisasi dan berjalannya suatu kebijakan, hal ini terkait dengan visi dan budaya dalam organisasi.

e. Strategi as a play. Strategi dalam pengertian ini berkaitan dengan bagaimana organisasi bermain terhadap maneuver spesifik organisasi yang bermaksud untuk mengalahkan rival atau competitor. $^{18}$

Strategi komunikasi yang menjadi bagian dalam proses perencanaan terjadi sebuah proses komunikasi, proses inilah yang menjadikan strategi komunikasi terdiri dari beragam rangkaian kegiatan sebagimana yang telah KPID Jawa Timur lakukan. Hal ini juga ditegaskan dalam buku Techniques for effectives Communication oleh R. Wayne Pace, Brent D. Paterson, dan M. Dallas Burnet, ketiganya menyebutkan

\footnotetext{
${ }^{18}$ Teuku May Rudi. Komunikasi dan Hubungan Masyarakat Internasional. Bandung: PT. Rafika Aditama, 2005. 63-64
} 
bahwa kegiatan komunikasi terdiri dari tiga tujuan utama yakni to establish acceptance yaitu proses membentuk maupun membina penerimaan dan kesepakatan, to secure understanding yaitu memberikan kepastian dan jaminan pemahaman sebuah pesan, dan yang terakhir yaitu to motive action berarti kegiatan dalam memotivasi dalam upaya agar terjadi sebuah tindakan ${ }^{19}$.

KPID Jawa Timur melakukan pembentukan dan pembinaan bagi segenap yang ada di dalamnya guna mencapai suatu kesepakatan bersama dalam upaya pencapaian visi dan misi Dalam strategi komunikasi yang dibangun KPID Jawa Timur. Dilanjutkan dengan memberikan kepastian dan jaminan akan sebuah informasi si yang faktual melalui kepastian dan jaminan terhadap Pesan yang disampaikan. Kemudian dalam sebuah kegiatan dibalut dengan motivasi agar menjadi sebuah tindakan yang konkrit dalam

19 Onong Uchjana Effendy. Ilmu Komunikasi Teori dan Praktek. Bandung: PT. Remaja Rosdakarya. 2007. 32

20 A.K. Jailani \& Rachman, R. F. Kajian Semiotik Budaya Masyarakat: Nilai pencapaian strategi komunikasi yang diharapkan oleh KPID Jawa Timur.

KPID Jawa Timur dalam menyusun strategi komunikasi dilakukan dengan tujuan yang jelas, oleh karena hal tersebut, pada saat merumuskan strategi komunikasi mempertimbangkan beberapa hal diantaranya; menyusun pesan, mengetahui dan mengenal khalayak, menetapkan metode yang digunakan, dan seleksi serta pemilihan media yang tepat, hingga memahami kultur Jawa Timur dengan keaneka ragaman budayanya. $^{20}$ Upaya dan langkah KPID Jawa Timur dalam membangun siaran berkualitas, secara program sudah terbentuk dalam rancangan yang sudah tertulis dalam aturan. Kemudian juga disebutkan dalam bentuk program-program yang direalisasikan. Ada bebrapa hal yang menjadi tugas KPID dalam membentuk siaran berkualitas, yatu pengawasan, Pembinaan, dan pemberlakuan sanksi.

Keislaman dalam Tradisi Ter-ater di Lumajang. MUHARRIK: Jurnal Dakwah dan Sosial, 3(02), 125-137, 2020 
Komunike, Volume XII, No. 2 Desember 2020

\section{Optimalisasi Media Sosial KPID}

\section{Jawa Timur}

Sosial media sejatinya memang sebagai media sosialisasi juga interaksi, menarik orang lain untuk melihat dan mengunjungi tautan yang berisi informasi mengenai dan lain-lain. Jadi wajar jika keberadaannya dijadikan sebagai media pemasaran yang paling mudah dan murah (lowcost) oleh perusahaan. Karena optimalisasi media sosial merupakan ujung tombak dalam pencapaian strategi komunikasi yang diharapkan guna tercapainya tujuan atau visi dan misi KPID Jawa Timur

Sebagai situs jejaring, media sosial memiliki peran penting dalam pembentukan perilaku. Hal ini disebabkan media sosial dapat memainkan peran sebagai media komunikasi. Komunikasi merupakan upaya menjadikan seluruh kegiatan perusahaan dapat menghasilkan citra atau image yang bersifat satu atu konsisten bagi perusahaan. ${ }^{21}$

Media sosial memiliki ciri dan karakteristik yang sangat unggul

21 Morisson. 2007. Periklanan Komunikasi Pemasaran Terpadu. Jakarta: Ramdina Perkasa. dibandingkan dengan media-media yang lain seperti radio televisi dan media cetak. Pada dasarnya setiap individu di era new media tidak terlepas dari smartphone di mana secara umum media sosial dengan basis android mendominasi dalam penggunaan smartphone dalam kehidupan sehari-hari. $^{22}$ sehingga mengoptimalkan peran media sosial merupakan hal yang utama dalam tercapainya tujuan dari strategi komunikasi sebagaimana yang dilakukan KPID Jawa Timur .

Begitupun lembaga Negara sebagai sentra pelayanan publik wajib melek internet. Yang artinya, punya kesadaran penuh untuk memanfaatkan kemajuan teknologi informasi dan komunikasi dalam melaksanakan tugas-tugasnya. Terlebih, bagi Lembaga Negara yang memiliki hubungan erat dengan bidang komunikasi dan berada di provinsi. KPID Jawa Timur merupakan mitra dari Dinas Komunikasi dan Informatika (Diskominfo). Secara khusus, pada

22 A. A. U. Nuha \& B. Subahri. Deotoritasi Guru di Era New Media. Bidayatuna: Jurnal Pendidikan Guru Mandrasah Ibtidaiyah 3 (2), 185-206 
tugas-tugas KPID yang berkaitan erat dengan sosialisasi dan komunikasi publik.

KPID Jawa Timur yang memiliki komitmen untuk bisa memanfaatkan teknologi informasi dan komunikasi dalam melakukan hubungan interaksi, baik dengan masyarakat maupun pemangku kepentingan lainnya, misalnya, stasiun televisi dan radio di seantero Jawa Timur. Apalagi, selama ini, stasiun televisi dan radio juga sudah menggunakan media sosial berbasis internet dalam melakukan kerja sehari-hari. Mereka memiliki akun facebook, twitter, dan instagram. Keberadaan akun media sosial akan memudahkan masyarakat untuk memberikan kritik, saran, dan masukan pada KPID Jawa Timur. Selain itu, KPID Jawa Timur juga bisa lebih mudah berkomunikasi dengan semua stasiun televisi maupun radio, sekaligus mengimplementasikan transparansi komunikasi.

Selama ini, KPID Jawa Timur sudah memiliki sejumlah akun media

23 Hansen, D., Dunne, C., \& Shneiderman, B. Analyzing Social Media sosial, antara lain, di Facebook (KPID Jawa Timur)dan twitter @kpidjatim. Penelitian kali ini akan membahas secara detail tentang pemanfaatan akun media sosial KPID Jawa Timur tersebut. Melalui pendekatan kualitatif dan studi kasus di sana, dengan cara melakukan observasi serta indepht interview dengan para pemangku kepentingan yang berhubungan dengan tugas KPID Jawa Timur, khususnya di bidang sosialisasi dan komunikasi publik. Instansi dan lembaga pemerintah di berbagai negara saat ini menggunakan berbagaimedia sosial blog, mikroblog, berbagi layanan, pesan teks, forum diskusi, kolaborasi alat editing, virtual worlds, dan layanan jaringan sosial untuk melibatkan warganya ${ }^{23}$. Karena sifat khas dan kekuatannya, teknologi media sosial sebagai daya tarik massa terletak pada kemampuannya untuk menciptakan sebuah dialog langsung dan interaktif. Ciri-ciri yang dimiliki media sosial di atas bisa dimanfaatkan oleh Lembaga Negara seperti KPID Jawa Timur sebagai peluang untuk

Networks with NodeXL, (Figure 1), 2-3, 2010 
Komunike, Volume XII, No. 2 Desember 2020

mengoptimalisasikan tugasnya. yang tidak benar (hoax) tentang virus Apalagi, tujuan media sosial yang Corona, hal ini tentunya merugikan dijelaskan di atas, bersisian pula masyakat dan berpengaruh pada dengan tujuan KPID Jawa Timur. Khususnya, di ranah sosialisasi atau menyebarkan informasi dan menyerap informasi dari masyarakat. Media sosial kekenian sudah dekat dengan kalangan muda atau pelajar ${ }^{24}$, hingga kalangan tua atau dari mana pun latar belakangnya.

\section{Strategi Komunikasi KPID Jawa Timur dalam Pencegahan} Penyebaran Wabah Virus Corona

Dalam fenemomena saat ini jika dianalisis melalui The Pervasive presence theory dalam strategi komunikasi KPID Jawa Timur dalam Pencegahan Penyebaran Wabah Corona, maka media penyiaran memiliki dominasi yang kuat dalam mempengaruhi masyarakat melalui pesan yang ofensif dan masuk pada wilayah pribadi, maka dari itu media perlu diatur agar masyarakat mendapat rujukan media yang dapat mewadahi aspirasi dan melindungi masyarakat dari maraknya informasi

\footnotetext{
24 Rio Febriannur Rachman, Alfarisi, S., \& Rozi, M. F. Penyuluhan Tentang Bermedia Sosial yang Baik Bagi
}

psikologis masyarakat.

Strategi komunikasi adalah proses manajemen perencanaan komunikasi dalam mencapai suatu efek komunikasi yang diinginkan. Menurut Hamijoyo efek komunikasi ini diinginkan ini meliputi kesadaran, pemikiran kritis, tanggung jawab dan partisipasi masyarakat. Sesuai dengan penjelasan tentang strategi komunikasi, maka dalam penelitian ini tentang pencegahan penyebaran wabah Corona, KPID berbasarkan surat edaran dari KPI Pusat menumbuh kesadaran masyarakat untuk berpatisipasi dalam menghadapi dan memerangi penyebaran wabah Corona.

Berdasarkan observasi yang dilakukan peneliti terhadap kegiatan yang dilakukan oleh komisioner beserta staff monitoring media KPID Jawa Tiimur melakukan tiga langkah strategi dalam pencegahan

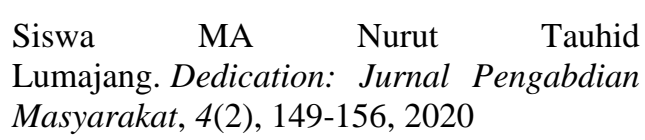


Komunike, Volume XII, No. 2 Desember 2020

penyebaran wabah Corona,

melakukan beberapa hal

diantaranya sebagai berikut:

diantaranya; mendukung instruksi

a. Memberikan surat edaran dan himbauan kepada lembaga penyiaran televisi dan lembaga penyiaran radio di Jawa Timur.

Televisi dan radio merupakan salah satu media massa yang banyak dikonsumsi masyarakat saat ini, hal ini karena akan kebutuhan masyarakat terhadap informasi, dan hiburan. Mulai dari kelas menengah ke bawah dan menengah ke atas dapat dengan mudah mengonsumsi informasi dari televisi dan radio, dikarenakan banyaknya jumlah lembaga penyiaran baik televisi dan radio saat ini, mulai dari lokal hingga nasional. Lembaga penyiaran televisi yang terdiri dari LPS TV Lokal 39, LPS TV SSJ 20, LPB 28, LPPL 1, LPP 1 yakni TVRI, dan LPK 2 dengan total 90.

Adapun untuk Lembaga Penyiaran Radio terdiri dari LPS 232, LPK 54, LPP 5 (RR), dan LPPL 18 dengan total radio 304. Dalam surat edaran ini KPID Jawa Timur menginstruksikan kepada lembaga penyiaran untuk

pemerintah dengan menginformasikan melalui Iklan Layanan Masyarakat (Spot atau ad lips) dan pernyataan host/reporter/penyiar yang menginformasikan secara massif tentang himbauan kepada masyarakat agar melakukan social distancing, mengubah format program siaran yang melibatkan banyak orang (peserta/audiens/penonton) baik disiarkan secara on air maupun off air, menghimbau lembaga penyiaran akan konten siaran yang ramah bagi semua umur dan mengutamakan perlindungan anak dan remaja dengan menyediakan program siaran pendidikan dan pembelajaran sebagai pengganti proses belajar dan mengajar, dan mengutamakan keselamatan para jurnalis dan kru penyiaran lainnya dengan menaati prokol pencegahan dan penanggulangan wabah Corona.

b. Strategi komunikasi kedua yaitu melalui kegiatan Talkshow dengan hadirnya komisioner 
Komunike, Volume XII, No. 2 Desember 2020

KPID Jawa Timur di lembaga penyiaran Televisi dan Radio yang disiarkan secara on air. Dalam Talkshow ini, Komisioner memberikan edukasi dan himbauan kepada masyarakat tentang literasi media terhadap pemberitaan terkait virus Corona, dan menjelaskan peran media penyiaran tentang pencegahan penyebaran wabah Corona. Literasi media yang dimaksudkan dalam hal ini merupakan himbauan kepada masyarakat untuk cerdas bermedia, tidak mudah terprovokasi pada pemberitaan media massa dan dapat memilih program siaran yang berkualitas, serta dapat menyaring informasi tentang pemberitaan Wabah Corona Komisioner pun menghimbau kepada masyarakat untuk tidak panik namun tetap waspada dengan adanya wabah Corona. Adapun untuk Talkshow ini dilakukan dibeberapa media diantaranaya; SBO TV, JTV, Radio Krisna FM Nganjuk, Radio Krisna FM Bojonegoro, Radio
Krisna FM Madiun, dan lain sebagainya.

c. Strategi komunikasi ketiga yang dilakukan oleh KPID Jawa Timur beserta Staff Media Monitoring dengan melalui media sosial instagram, mengingat instagram menjadi media sosial yang menjadi rujukan dan digemari oleh para milenial dalam mencari informasi. Dalam instagram KPID Jawa Timur memberikan informasi terkait himbauan dalam literasi media televisi dan radio ketika masyarakat bekerja dari rumah, himbauan menggunakan masker, serta publikasi informasi lainnya yang menjadi program Pemerintah Provinsi Jawa Timur sebagai contoh program Itighotsah Kubro "Dzikir dan Doa 19 Kyai Sepuh, Gubenur dan FORKOPIMDA, dan informasi tentang update jumlahh persebaran masyarakat yang positif virus Corona.

KPID Jawa Timur memanfaatkan arus informasi di ruang publik, baik melalui media sosial berbasis internet, maupun melalui forum-forum diskusi tatap 
Komunike, Volume XII, No. 2 Desember 2020

muka. Dalam buku Between Facts and Norms, ruang publik ditempatkan sebagai elemen dari bangunan teoritis tentang demokrasi deliberatif. Demokrasi deliberatif adalah arus balik dari demokrasi klasik-ortodoks yang memahami demokrasi semata dalam kerangka agregasi preferensi dan kepentingan warga negara melalui sarana konvensional seperti pemungutan suara dan lembaga perwakilan $^{25}$. Inti dari demokrasi ini adalah bahwa sebuah keputusan akan terlegitimasi apabila telah mendapat persetujuan rasional lewat partisipasi di dalam pertimbangan mendalam (deliberation) yang otentik oleh semua pihak yang berkepentingan terhadap keputusan tersebut. Habermas menilai, ruang publik adalah arena bagi setiap orang untuk berpartisipasi dalam upaya deliberasi.

Kehadiran media sosial berbasis internet telah menyebabkan berkembangnya konsep mengenai ruang publik. Interaksi-interaksi yang membahas mengenai permasalahan

25 John Dryzek. Deliberative Democracy And Betond : Liberals, Critics, Contestations. Oxford: Oxford University Press, 2000

26 David Holmes, Communication Theory Media, Technology, Society. publik berlangsung pula di dalam lingkungan virtual dengan menggunakan perantara komputer (Computer Mediated Communication atau CMC). David Holmes ${ }^{26}$ menyatakan, setiap saat individu selalu bersinggungan dengan teknologi informasi dan hidup dalam sebuah masyarakat informasi. Relasi antar individu pun tidak lagi terbatas pada relasi fisik, melainkan juga relasi interface yang diwakili oleh perangkat teknologi komunikasi. Dalam perubahan yang sedemikian rupa, ruang publik tidak lagi hanya berlangsung dalam ruang-ruang fisik, namun juga dalam ruang-ruang virtual $^{27}$.

Sebagaimana the pervasive presence theory masyarakat mengkonsumsi media penyiaran dengan skala besar baik melalui televisi radio dan internet Dengan basis media sosial. KPID Jawa Timur telah mengupayakan dalam pencegahan wabah virus Corona dengan memanfaatkan dan media

Communication Theory. Thousand Oaks, CA: SAGE Publications, Ltd, 2005

27 Eben Haezer, Creative Media Project: Ruang Publik Virtual dalam Laman Forum Online Wicara. co (Doctoral dissertation, Universitas Airlangga), 2017 
Komunike, Volume XII, No. 2 Desember 2020

sebagai ujung tombak dalam mengatasi wabah yang menjadi keresahan masyarakat saat ini. Perencanaan, pelaksanaan hingga evaluasi dalam pencegahan virus Corona yang dilakukan baik dalam penggunaan media televisi radio hingga media internet berupa Instagram dilakukan secara berkesinambungan sehingga hal ini ini bisa optimal dan meminimalisir penyebaran wabah virus Corona yang semakin tak terkendali.

\section{E. KESIMPULAN}

The Pervasive presence theory merupakan teori tentang media penyiaran memiliki pengaruh dan dominasi yang kuat terhadap masyarakat. Oleh karena itu, KPID Jawa Timur sebagai lembaga independen melakukan pengawasan terhadap media penyiaran. Dalam ranah saat ini ditengah adanya bencana besar yaitu wabah pandemi Corona, KPID Jawa Timur melakukan strategi komunikasi dalam pencengahan penyebaran virus Corona.
Strategi komunikasi ini dilakukan dengan tiga cara yaitu Talkshow tentang peran media massa dalam memerangi virus corona, sosialisasi melalui media sosial instagram KPID Jawa Timur, dan Surat Edaran melalui email dan whatsapp kepada lembaga penyiaran baik televisi maupun radio di seluruh wilayah Jawa Timur. Ketiga strategi ini dilakukan menjadi bagian upaya literasi media ditengah wabah Corona melanda Indonesia, dan menjadikan masyarakat untuk tidak panik namun selalu waspada serta dapat menerapkan pola hidup bersih dan sehat demi kenyamanan bersama. 
Komunike, Volume XII, No. 2 Desember 2020

F. DAFTAR PUSTAKA

Arifin, Anwar. (2007). Strategi Komunikasi Sebuah Pengantar Ringkas. Bandung: CV Armico

Asshiddiqie, Jimly. (2010). Konstitusi dan Konstitusionalisme Indonesia, Jakarta: Sinar Grafika

Atkinson, Rita L dkk. (2010). Pengantar Psikologi. Tangerang: Interaksara

Dryzek, John. (2000). Deliberative Democracy And Betond : Liberals, $\quad$ Critics, Contestations. Oxford: Oxford University Press

Effendy, Onong Uchjana. (2006). Ilmu Komunikasi Teori dan Praktek. Bandung: PT Remaja Rosdakarya

Haezer, Eben, (2017). Creative Media Project: Ruang Publik Virtual dalam Laman Forum Online Wicara. co (Doctoral dissertation, Universitas Airlangga).

Hansen, D., Dunne, C., \& Shneiderman, B. (2010).
Analyzing Social Media Networks with NodeXL,

(Figure 1), 2-3.

Holmes, D. (2005). Communication Theory Media, Technology, Society. Communication Theory. Thousand Oaks, CA: SAGE Publications, Ltd

J Moleong, Lexy. (2008). Metodologi Penelitian Kualitatif. Bandung: PT. Rosda Karya Kuswarno, Engkus. (2009). Metodologi Penelitian Komunikasi Fenomenologi: Konsepsi, Pedoman, dan Contoh Penelitian Fenomena Pengemis Kota Bandung. Bandung: Widya Padjadjaran Masduki. (2007). Regulasi Penyiaran: dari Otoriter ke Liberal. Yogyakarta: LKIS Yogyakarta

Nurudin. (2007). Komunikasi Massa. Malang: Cespur

Oliver, Sandra. (2007). Strategi Public Relations.Jakarta: PT Gelora Aksara Pertama 
Komunike, Volume XII, No. 2 Desember 2020

R. Semiawan, Conny. (2008).

Jurnal Sosial \& Budaya Syar-

Metode Penelitian Kualitatif

Jenis Karakteristik dan

Keunggulannya. Jakarta:

Grasindo

i FSH UIN Syarif

Hidayatullah Jakarta Vol. 7

No. 5 (2020), pp. 395-402,

DOI:

Rakhmat, Jalaluddin. (2009). Metode

10.15408/sjsbs.v7i5.15314

$\begin{array}{llr}\text { Penelitian } & \text { Komunikasi. } \\ \text { Bandung } & \text { Remaja } \\ \text { Rosdakarya } & & \end{array}$

Rudi, Teuku May. (2005).

Komunikasi dan Hubungan

Masyarakat Internasional.

Bandung: PT. Rafika Aditama

Termorshuizen, Marjanne. (2002).

Kamus Hukum Belanda-

Indonesia, Jakarta:

Djambatan

W Creswell, John. (2009). Research

Design Pendekatan Kualitatif,

Kuantitatif, dan Mixed.

Yogyakarata: Pustaka Pelajar,

Edisi Ketiga

Wiryanto. (2000). Teori Komunikasi

Massa. Jakarta: Grasindo

Aji, R. H. S. (2020). Dampak Covid19 pada Pendidikan di Indonesia: Sekolah, Keterampilan, dan Proses

Ghofur, A \& Subahri, B. (2020). Konstruksi Sosial Keagamaan Masyarakat Pada Masa Pandemi Covid-19. DAKWATUNA: Jurnal Dakwah dan Komunikasi Islam. Volume 6, Nomor 2, Agustus 2020.

Jailani, A. K., \& Rachman, R. F. (2020). Kajian Semiotik Budaya Masyarakat: Nilai Keislaman dalam Tradisi Terater di Lumajang. MUHARRIK:

Jurnal Dakwah dan Sosial, 3(02), 125-137.

Pembelajaran. SALAM; 
Kurniawan, A., Yumna, N., \& Tantri, E. (2020). Resistensi Ruang Publik Di Tengah Covid-19 Perspektif Islam Dan Komunikasi

Multikultural. KOMUNIKE, 1 2(1), 24-40.

https://doi.org/10.20414/jurko m.v12i1.2253

Nuha, A.A.U., \& Subahri. B. (2020) Deotoritasi Guru di Era New Media. Bidayatuna: Jurnal Pendidikan Guru Mandrasah Ibtidaiyah 3 (2), 185-206

Panuju, Rendi. (2018). Strategi Berjaringan Radio Komunitas Islam Madu FM Tulungagung.Jurnal Sosiologi Reflektif. Vol 12, No 2

Rachman, R. F., \& Ilmaniya, S. (2020). KOMUNIKASI ANTARBUDAYA DI PONDOK PESANTREN

(Studi Kasus di Pondok Pesantren Putri Miftahul Ulum Banyuputih

Lumajang). Al-Insyiroh:

Jurnal Studi Keislaman, 6(2), 61-84.
Rachman, R. F., Alfarisi, S., \& Rozi, M. F. (2020). Penyuluhan Tentang Bermedia Sosial yang Baik Bagi Siswa MA Nurut Tauhid Lumajang. Dedication:

Jurnal Pengabdian Masyarakat, 4(2), 149-156.

Thaha, A. F. (2020). Dampak Covid19 Terhadap Umkm Di Indonesia. Jurnal Brand, Volume 2 No. 1, Juni 2020.

Utoyo, A. W. (2020). Analisis Komunikasi Visual Pada Poster Sebagai Media Komunikasi Mendorong Jarak Sosial Di Jakarta Saat Epidemi Covid 19. Jurnal Lugas Vol. 4, No.1, Juni 2020, pp. $35-42$

Vardhani, Nabilla Kusuma \& Agnes Siwi Purwaning Tyas. (2018). Strategi Komunikasi dalam Interaksi dengan Mahasiswa Pertukaran Asing. Jurnal Gema Societa (2), 1

Wahyuningsih, L. N., \& Rachman, R. F. (2020). Communication of Caregivers and Santri at 
Komunike, Volume XII, No. 2 Desember 2020

Islamic Boarding Schools in a

Gender Perspective. Kanal:

Jurnal Ilmu Komunikasi, 9(1),

9-15.

https://doi.org/10.21070/kana

$\underline{1 . v 9 i 1.628}$

Kemeterian Kesehatan RI. (2020).

Pedoman Kesiapsiagaan

Menghadapi Infeksi Novel

Coronavirus (2019-nCoV).
Jakarta: Direktorat Jenderal

Pencegahan dan Pengendalian

Penyakit

Dian Erika Nugraheny. Mendagri

Keluarkan Surat Edaran soal Pembentukan Gugus Tugas

Penanganan Covid-19 di

Daerah. Dikutip dari

Kompas.com 